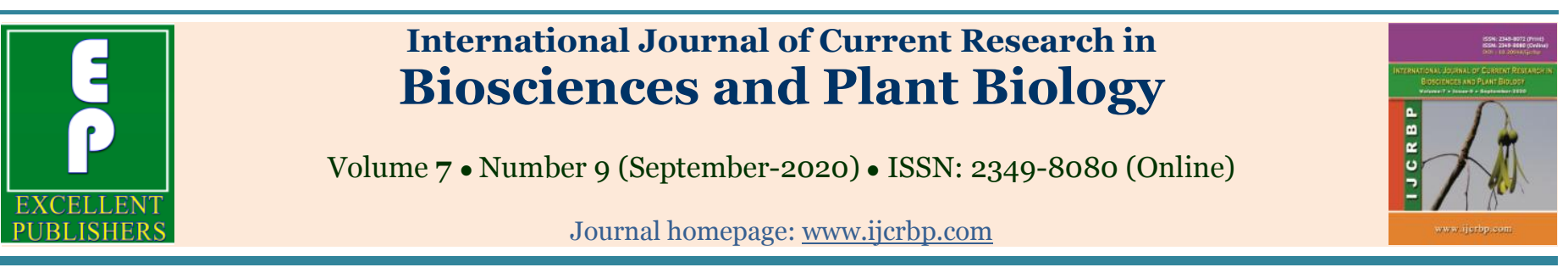

\title{
Floristic diversity of woody stands of the Sudano Guinean Savannah of Mbam and Djerem National Park (PNMD), Cameroon
}

\author{
Dadem Gueguim Christelle ${ }^{1^{*}}$, Tchamba N. Martin' and FOTSO Roger Corneille ${ }^{2}$
}

${ }^{1}$ Department of Forestry, Faculty of Agronomy and Agricultural Sciences, University of Dschang, Cameroon ${ }^{2}$ Wildlife Conservation Society (WCS), Cameroon Biodiversity Program, Tél.: + 237222202645 ; B.P.: 3055 Messa-Yaoundé

*Corresponding author; e-mail: christelledadem@yahoo.fr

\begin{tabular}{|c|c|}
\hline Art & $\mathbf{B S}$ \\
\hline $\begin{array}{l}\text { Date of Acceptance: } \\
28 \text { August } 2020\end{array}$ & \multirow{3}{*}{$\begin{array}{l}\text { The combined effect of climatic deterioration and anthropogenic pressure has caused a } \\
\text { gradual degradation of the natural resources of the Mbam and Djerem National Park. } \\
\text { This phenomenon has not spared the woody stratum which constitutes in this region } \\
\text { the main source of forage in the dry season. The rehabilitation of these ecosystems } \\
\text { necessarily requires precise ecological knowledge, hence the interest in making a } \\
\text { diagnosis of the floristic diversity of the woody stratum. The dendrometric sampling } \\
\text { method was used for this study carried out in Mbam and Djerem National Park. This } \\
\text { inventory consisted in systematically identifying all the woody species by height class in } \\
3 \text { sites according to factor gradients. This method made it possible to inventory a total } \\
\text { of } 1,596 \text { trees, divided into } 45 \text { species belonging to } 24 \text { families. Statistical processing of } \\
\text { data obtained in the field shows that the flora is dominated by the family of } \\
\text { Euphorbiaceae, Combretaceae, Fabaceae and Rubiaceae group together the maximum } \\
\text { of species with, respectively, } 7 \text { and } 4 \text { listed for the others. The richness of flora is more } \\
\text { important in Kpayere which presents a weak similarity with Debiro. }\end{array}$} \\
\hline Keywords & \\
\hline $\begin{array}{l}\text { Flori } \\
\text { Prote } \\
\text { Sava } \\
\text { Susta }\end{array}$ & \\
\hline
\end{tabular}

\section{Introduction}

Savannahs constitute a complex ecosystem marked by the coexistence of a herbaceous layer and one or more shrub and / or tree layers under the effect of the interaction of several environmental factors: varied rainfall regimes, role of fire and breeding. The savannahs are clearly distinguished from the closed environments of the dense forest; the contact between the two facies can be linear and straightforward, or more complex when intermediate forest formations are interposed or when a forest-savanna mosaic ensures the transition (Lamine et al., 2009). Savannahs are ecosystems playing major ecological, socioeconomic, and environmental roles in the world. Rich in endemic species, they contribute strongly to global biodiversity (Demers-Lemay, 2014; Ousmane et al., 2018). In addition, their high forage value allows them to support the largest populations of wild and domestic herbivores on the planet (N'dri, 2011; Ousmane et al., 2020).

During the rainy season, the pasture consists mainly of the herbaceous layer whereas in the dry season, the woody layer contributes very strongly to the feeding of the cattle. As in all pastoral areas, 
wood resources play an important role in feeding livestock and meeting the needs of the populations of Mbam and Djerem national park. However, these resources have known for more than four decades, a process of significant degradation as a result of climate change and multiple human interventions. This deterioration results in a regression of certain woody species correlated with the expansion of others (MINFOF, 2017). At the same time, the average density of woody trees in the area has decreased significantly in recent decades, with the consequences of land depletion, soil erosion, etc.

Faced with this context, strategies for rehabilitating these ecosystems are not known in the PNMD. Indeed, for the success of these strategies, it is necessary to set up a sustainable management in order to restore the protective role of woody plants on sensitive soil substrates. This sustainable management requires precise knowledge in certain fundamental areas of ecology, such as vegetation dynamics, biodiversity conservation and the process of restoring an ecosystem. This is the framework for this study, which aims to determine and assess the characteristics of the flora. More specifically, it is a question of determining the richness and the floristic composition of the savannah of the protected area and of characterizing the structure of the vegetation.

\section{Materials and Methods}

\section{Study area}

The specific vulnerability of savannahs in protected areas (PA) led this study to focus on the PNMD, which are considered priorities at the national level. The choice fell on this protected area to respond to: a request from the NGO Wildlife conservation society (WCS) which is funding the PNMD / WCS Development Support project; at the request of park managers who consider fire as one of the tools for land management and protection (Grégoire et al., 2003); scientific questions that the same managers are asking about the impact of fires on the nature and structure of plant cover. The Mbam and Djerem National Park is located between $5^{\circ} 30^{\prime}$ and $6^{\circ} 13^{\prime}$ north latitude, and $12^{\circ}$ $13^{\prime}$ and $13^{\circ} 10^{\prime}$ east longitude. This park extends over the Center, East and Adamaoua regions, in the heart of Cameroon. It is located at the southern limit of the Adamawa plateau and on the northern edge of the dense forest of the Congo Basin (Fig. 1). There is both the equatorial rain forest (to the south and east) and areas of Savannah-Guinean type with a rainfall of $1800 \mathrm{~mm}$ Created in January 2000, the park covers a total area of 416512 ha, half of which is lowland tropical forest. The other half of the savannah is wooded and wooded. Between the two, there is a large belt of ecotone, that is to say overlapping of the two contiguous zones. This overlap provides the Mbam and Djerem national park with a great diversity of habitats and therefore a great biodiversity (MINFOF, 2016).

\section{Methods}

\section{Experimental setup}

This study was carried out as part of the PAAPNMD / WCS project in 2018, on three sites in shrub savannah. These sites were chosen based on accessibility, proximity to the forest-savannah transition zone and the periphery of the park. A system of 1.89 ha (1.5 ha of plots and 0.39 ha of firewall) has been defined by site. Each device includes three plots of $40 \mathrm{mx} 125 \mathrm{~m} \mathrm{(1/2} \mathrm{ha).} \mathrm{Each}$ corner of the plots was marked with the help of the markers (the $2 \mathrm{~m}$ poles and signed with the marking strip (fluorescent tape, sign plate) and the GPS points of each corner were also noted (Fig. 2).

\section{Woody stratum inventory}

The inventory of the woody stratum was carried out at the 3 sites. This inventory consisted of systematically identifying all woody species by height class. The individuals were divided into the following height categories:

* Class 1 grouping individuals of height less than 1 $\mathrm{m}$; it corresponds to regeneration;

* Class 2 grouping individuals of height between 1 and $3 \mathrm{~m}$ : this is the class of juveniles;

* Class 3 with individuals higher than $3 \mathrm{~m}$. these are adults.

The following parameters were recorded during the inventories:

* The scientific name of the species; 
* The class of the individual;

* Phenology.

Phenophases follow the distribution of Savadogo (2002). However, we adapted taking into account the fire factor. It is:

a) Leafing with:

- $\mathrm{FeO}=$ absence of leaves

- Fe1 = start of leafing corresponding to bud burst

- Fe2 = full leaf

- $\mathrm{Fe} 3$ = end of leafing marked by the senescence of the leaves and their fall.

- $\mathrm{Fe} 4=$ presence on the tree of leaves dried by fire. Combinations of phenophases give codifications such as Fe1.4 or Fe2.4. This is due to the fact that after the passage of the fires, the individual can start again to give young leaves without the old leaves burnt by the fire not having completely dropped.

\section{b) Flowering with:}

- FI1 = start of flowering (flower buds on the tree)

- FI2 = full bloom (blooming flowers on the tree)

- $\mathrm{FI} 3=$ presence on the tree of flowers dried by fire.

c) Fruiting with:

- Fr1 = start of fruiting

- Fr2 = full fruiting

- Fr3 = end of fruiting (ripe fruit of the year)

- Fr4 = presence of fire-dried fruit.

These data made it possible to estimate the woody specific richness of the PNMD, the stratification of woody species.

\section{Data processing}

The data processing was carried out with the Excel spreadsheet of Microsoft Office 2016, in order to assess the floristic diversity of the woody stands. The data collected were analyzed, the list of species inventoried and their taxonomies drawn up in order to assess the floristic composition.

The Relative Density, the floristic similarity and the diversity of the three study areas were estimated through the following indices:

\section{Relative density}

It is the measure of the density of a species in an area or in a community in relation to the total number of individuals of all species in the same unit. It is often expressed in\% and is calculated by:

Relative density $=(\mathrm{Na} / \mathrm{NT}) \times 100$ with $\mathrm{Na}$ expresses the number of individuals of the species, NT expresses the number of individuals of all species

\section{Floristic similarity between the three study sites}

It was estimated using the qualitative Jaccard index $\mathrm{Cj}=\mathrm{J} /(\mathrm{a}+\mathrm{b}-\mathrm{J})$ and the quantitative index of Morisita.

$$
\mathrm{C}_{\mathrm{MH}}=\frac{2 \sum\left(\mathrm{an}_{\mathrm{i}} \times \mathbf{b n}_{\mathrm{i}}\right)}{(\mathrm{da}+\mathrm{db}) \mathrm{aN} \times \mathbf{b N}}
$$

For the Jaccard index: $\mathrm{j}=$ number of species common to the two sites in comparison; $a$ and $b$ are the respective species numbers of the two sites.

For the Morisita index: $\mathrm{aN}=$ number of individuals from site $\mathrm{A}, \mathrm{bN}=$ number of individuals from site $\mathrm{B}$, ani; = number of individuals of species $\mathrm{i}$ in site $\mathrm{A}$, bni. = number of individuals of species $\mathrm{i}$ in site B. $\mathrm{da}=\frac{\sum_{\mathrm{mn}_{1} 2}}{\mathrm{aN}^{1}}$ and $\mathrm{db}=\frac{\sum_{\mathrm{bn}_{1} 2} 2}{\mathbf{b N}^{1}}$

\section{Diversity of the three study sites}

Indices were used to characterize the diversity in these three study areas. These are: $\mathrm{N}$ : the number of individuals surveyed, $\mathrm{S}$ : the total number of species surveyed, S / N: the ratio of the number of species to the number of individuals surveyed

- Margalef's index on specific wealth: $\mathrm{D}=(\mathrm{S}-1) / \ln \mathrm{N}$

- Shannon's index on regularity: $\mathrm{J}^{\prime}=\mathrm{H}^{\prime} / \mathrm{InS}$

- Shannon-Wiener's index:

$$
\begin{gathered}
\mathbf{H}^{\prime}=-\sum \mathbf{P}_{\mathbf{1}} \log _{2} \mathbf{P}_{\mathbf{i}} \\
\text { avec } \boldsymbol{P i}=\frac{n_{i}}{N} \text { proportional abundance of species i }
\end{gathered}
$$

- The converse of the Simpson's index:

$$
1 / \mathfrak{h}=\sum \mathbf{n}_{\mathbf{i}}\left(\mathbf{n}_{\mathbf{i}}-\mathbf{1}\right) \frac{\mathfrak{h}}{\mathrm{N}_{\mathbf{1}}\left(\mathrm{N}_{\mathbf{1}}-\mathbf{1}\right)}
$$

with $\mathrm{n}$, the number of individuals in the species $\mathrm{i}$ of a site, $\mathrm{N}$ being the total number of individuals of this same site. 


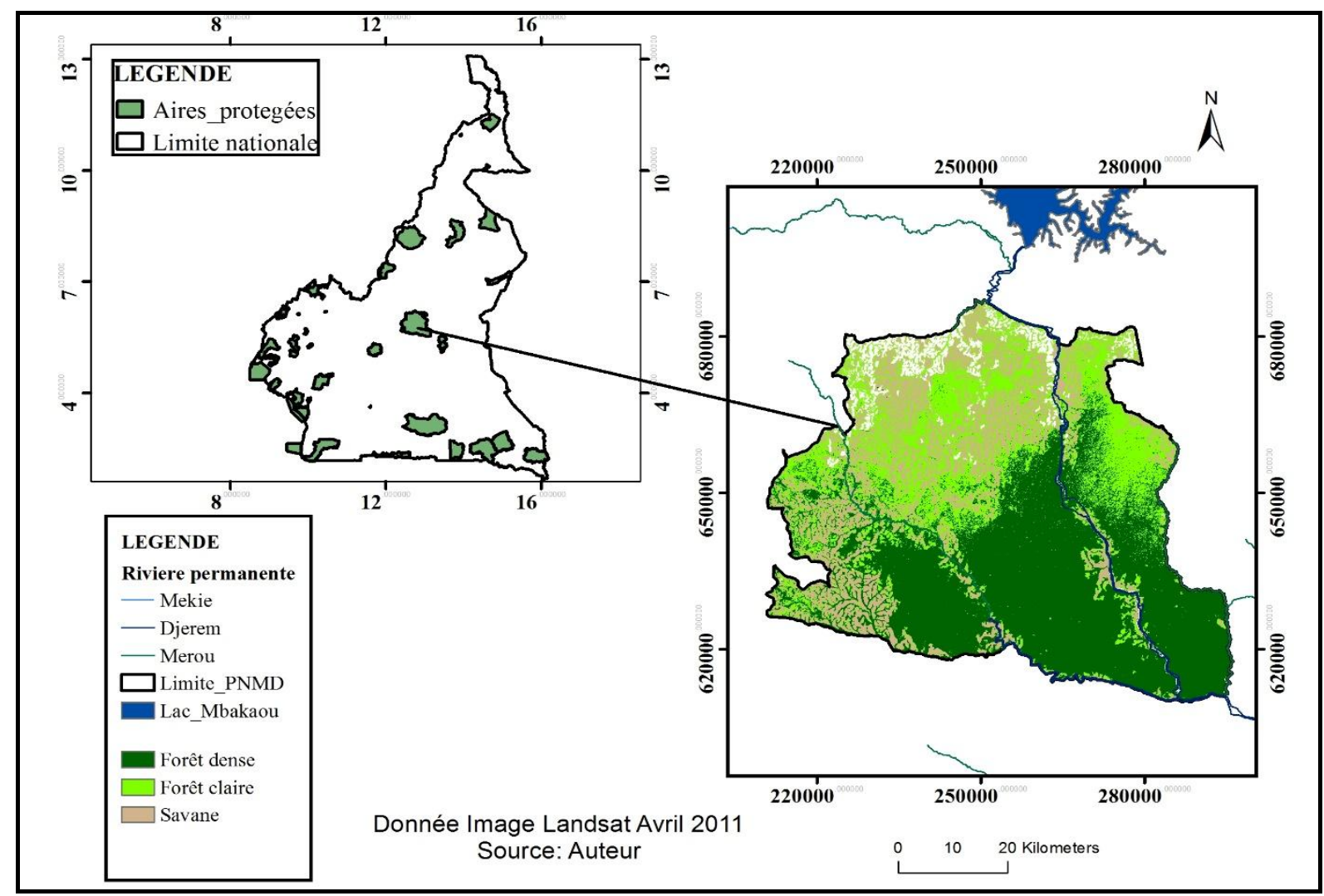

Fig. 1: Geographical location of the study area.
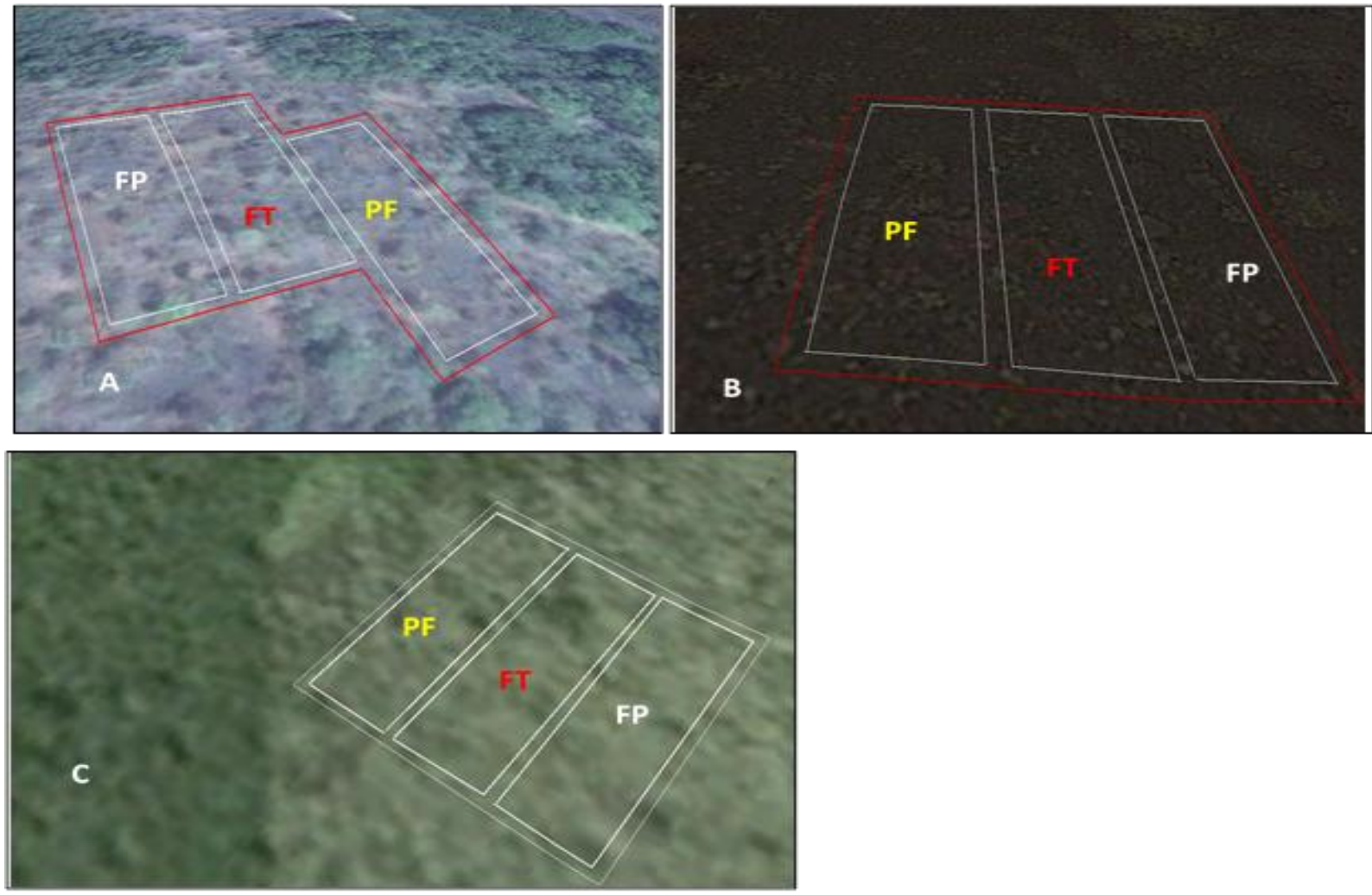

Fig. 2: Photograph showing the arrangement of the experimental plots. 


\section{Results}

\section{Woody stratum inventory}

\section{Specific wealth}

A total of 1,596 trees, divided into 45 species belonging to 24 families, have been identified. The Euphorbiaceae Combretaceae, Fabaceae and Rubiaceae family groups together the maximum number of species with, respectively, 7 and 4 listed for the others.

\section{Vertical structure}

One of the major problems with this food resource is the accessibility of animals to wood fodder (Samaya, 2005, Savadogo, 2011).

Figure 3 shows the distribution of woody individuals by height category (seedling $=\mathrm{H}<1 \mathrm{~m}$; juveniles $=1 \mathrm{~m}<\mathrm{H}<3 \mathrm{~m}$; Adults $=\mathrm{H}>=3 \mathrm{~m}$ ).

Figure 3 shows a dominance of small individuals, reflecting a strong regeneration of the species. Semis represent $48.26 \%$, juveniles $28.69 \%$ and adults 23.05\%. This dominance of small individuals could be linked to the impact of bush fires permanently rejuvenating stands.

\section{Floristic similarity between the three study areas}

The similarity indices for the Miyere, Debiro and Kpayere zones are presented in Table 2.

The Jaccard index, which takes into account only the species present, shows a fairly high similarity (more than 50\%) between the three zones taken 2 to 2.

However, the Morisita index which, in addition to the species present, includes their relative abundance, shows that the similarity is very low (20\%) between on the one hand, Miyere and Debiro and on the other hand, Debiro and Pkayere. This similarity is not very different (48.4\%) between Miyere and Pkayere. These indices confirm, after the physiognomic aspects observed in the field, that these three zones are very different and deserve to be studied separately.

\section{Diversity of the three study areas}

Table 3 shows the diversity of woody plants in the three study sites. Legend: $\mathrm{N}=$ the number of individuals surveyed, $\mathrm{S}=$ total number of species surveyed, $\mathrm{S} / \mathrm{N}=$ ratio of the number of species to the number of individuals surveyed, $\mathrm{D}=$ Margalef's index on specific wealth, $J{ }^{\prime}=$ the Shannon index on regularity, $\mathrm{H}^{\prime}=$ the Shannon-Wiener index, $1 / \lambda=$ reciprocal of the Simpson index.

It appears from this table that the different calculated indices compete to classify the three zones in terms of decreasing diversity, in the following order: Kpayere, Miyere, and Debiro.

\section{Discussion}

In the savannas of the PNMD, the woody flora inventoried is rich with 45 species. The family of Euphorbiaceae Combretaceae, Fabaceae and Rubiaceae groups together the maximum of species with, respectively, 7 and 4 listed for the others. This situation is not specific to PNMD. Indeed, the dominance of these families is a fairly general phenomenon for most protected areas (Ousmane et al., 2020). This floristic richness is variable according to the sites, it is higher in Kpayere and lower in debiro. This procession of species which includes endemic, rare and endangered species would fully justify the membership of the PNMP forest in the "Guinean Forests of West Africa Hotspot", one of the 36 tropical zones of global importance for their biodiversity (Michael et al., 2016).

The woody flora of the PNMD savannas is therefore richer in the central part compared to the North. This difference in flora richness could be explained in addition to the drastic climatic conditions, by the practice of agriculture and animal husbandry in the North which would seem to be a transition zone between the sylvo-pastoral zone and the forest. Indeed, the climate plays an essential role in the composition and the floristic structure (Sarr, 2008). According to Wezel (2004) more than the climatic factor, it is the anthropic pressure which completes the disappearance of the species therefore of the biodiversity after the climatic changes will have resulted in the loss of density of the woody species (Gonzalez, 2001). 
Table 1. Main woody species and families of the three systems and their densities in the PNMD.

\begin{tabular}{|c|c|c|c|c|}
\hline \multirow[b]{2}{*}{ Family } & \multirow[b]{2}{*}{ Species } & \multicolumn{3}{|c|}{ Density (No. / ha) } \\
\hline & & $\begin{array}{l}\text { Miyere } \\
\text { device }\end{array}$ & $\begin{array}{l}\text { Debiro } \\
\text { device }\end{array}$ & $\begin{array}{l}\text { Pkayere } \\
\text { device }\end{array}$ \\
\hline Mimosaceae & Albizia zygia & 2 & 2 & 16 \\
\hline Sapindaceae & Allophylus africanus & 2 & O & 2 \\
\hline Annonaceae & Annona senegalensis & 55 & 30 & 66 \\
\hline Euphorbiaceae & Antidesma venosum & 3 & O & o \\
\hline Palmaceae & Borassus aethiopum & 4 & $\mathrm{O}$ & o \\
\hline Euphorbiaceae & Bridalia ferugina & 7 & 12 & 74 \\
\hline Combretaceae & Combretum fragrans & 5 & 5 & 23 \\
\hline Rubiaceae & Crossopteryx febrifuga & 25 & 10 & 28 \\
\hline Araliaceae & Cussonia arborea & 10 & 58 & 1 \\
\hline Caesalpiniaceae & Daniellia oliveri & 15 & 5 & o \\
\hline Mimosaceae & Entada africana & 2 & 2 & o \\
\hline Fabaceae & Erythrina sigmoedae & 1 & O & o \\
\hline Moraceae & Ficus exasterata & 21 & 9 & o \\
\hline Moraceae & Ficus mucosa & o & 5 & o \\
\hline Euphorbiaceae & Phyllanthus muclerianus & 4 & 1 & 1 \\
\hline Euphorbiaceae & Hymenocardia acida & 52 & 77 & 122 \\
\hline Annacardiaceae & Lannea welwitschii & $\mathrm{o}$ & 3 & 3 \\
\hline Ochnaceae & Lophira lanceolata & 2 & 8 & 5 \\
\hline Euphorbiaceae & Maproumea africana & 13 & 6 & 10 \\
\hline Euphorbiaceae & Margaritaria discoidae & 1 & $\mathrm{o}$ & o \\
\hline Bignoniaceae & Markhamia tomentosa & 1 & o & o \\
\hline Celastraceae & Maytenus sengalensis & 125 & 144 & o \\
\hline Rubiaceae & Nauclea laticolia & 23 & 1 & 21 \\
\hline Mimosaceae & Parkia biglobosa & 3 & 5 & 1 \\
\hline Fabaceae & Pedocarpus lusens & 1 & o & o \\
\hline Fabaceae & Piliostigma thonningii & 25 & 40 & 51 \\
\hline Proteaceae & Protea madiensis & 6 & 14 & 6 \\
\hline Bignoniaceae & Stereospermum kunthianum & 3 & 38 & o \\
\hline Logonaceae & Strichnons spinosa & 2 & o & o \\
\hline Myrtaceae & Syzygium guineense & 7 & 2 & 23 \\
\hline Combretaceae & Terminalia glaucescens & 7 & o & 7 \\
\hline Combretaceae & Terminalia macroptera & 7 & 71 & o \\
\hline Combretaceae & Terminalia albizia & o & 0 & 81 \\
\hline Fabaceae & Terocarpus lucens & 1 & o & o \\
\hline Meliaceae & Trichilia emetica & 3 & 2 & 9 \\
\hline Verbenaceae & Vitex doniana & 14 & 7 & 1 \\
\hline Olacaceae & Ximenia americana & 7 & 16 & o \\
\hline Euphorbiaceae & Wapaka guineensis & o & 1 & o \\
\hline Rubiaceae & Psychotria mbibiensis & o & o & 1 \\
\hline Anarcadiaceae & Spondias mombin & o & o & 2 \\
\hline Polygalaceae & Securidaca longepedunculata & o & o & 1 \\
\hline Rubiaceae & Sarcosephalu latifolius & o & o & 6 \\
\hline Clusiaceae & Harungana madagascariensis & o & o & 1 \\
\hline Ochnaceae & Ochna afzellii & o & o & 1 \\
\hline Apocynaceae & Funtumia elastica & $\mathrm{O}$ & $\mathrm{O}$ & 2 \\
\hline
\end{tabular}


Table 2. Floristic similarities between the specific woody compositions of the Miyere, Debiro and Kpayere systems in the PNMD.

\begin{tabular}{llc}
\hline Comparison between plant communities & Jaccard index (\%) & Morisita index (\%) \\
\hline Miyere/ Debiro & 0.648 & 0.178 \\
Miyere / Pkayere & 0.576 & 0.484 \\
Debiro/ Pkayere & 0.586 & 0.128 \\
\hline
\end{tabular}

Table 1. Woody diversity of the three zones in the PNMD.

\begin{tabular}{llllllll}
\hline Zone & $\mathbf{N}$ & $\mathbf{S}$ & $\mathbf{S} / \mathbf{N}$ & $\mathbf{D}$ & $\mathbf{J}^{\prime}$ & $\mathbf{H}^{\prime}$ & $\mathbf{1} / \boldsymbol{\chi}$ \\
\hline Miyere & 451 & 35 & 0.076 & 5.545 & 0.975 & 3.794 & 0.1319 \\
Debiro & 590 & 27 & 0.047 & 4.092 & 0.894 & 3.442 & 0.162 \\
Kpayere & 555 & 28 & 0.049 & 4.417 & $\mathbf{1 . 0 5 0}$ & 4.130 & 0.094 \\
\hline
\end{tabular}

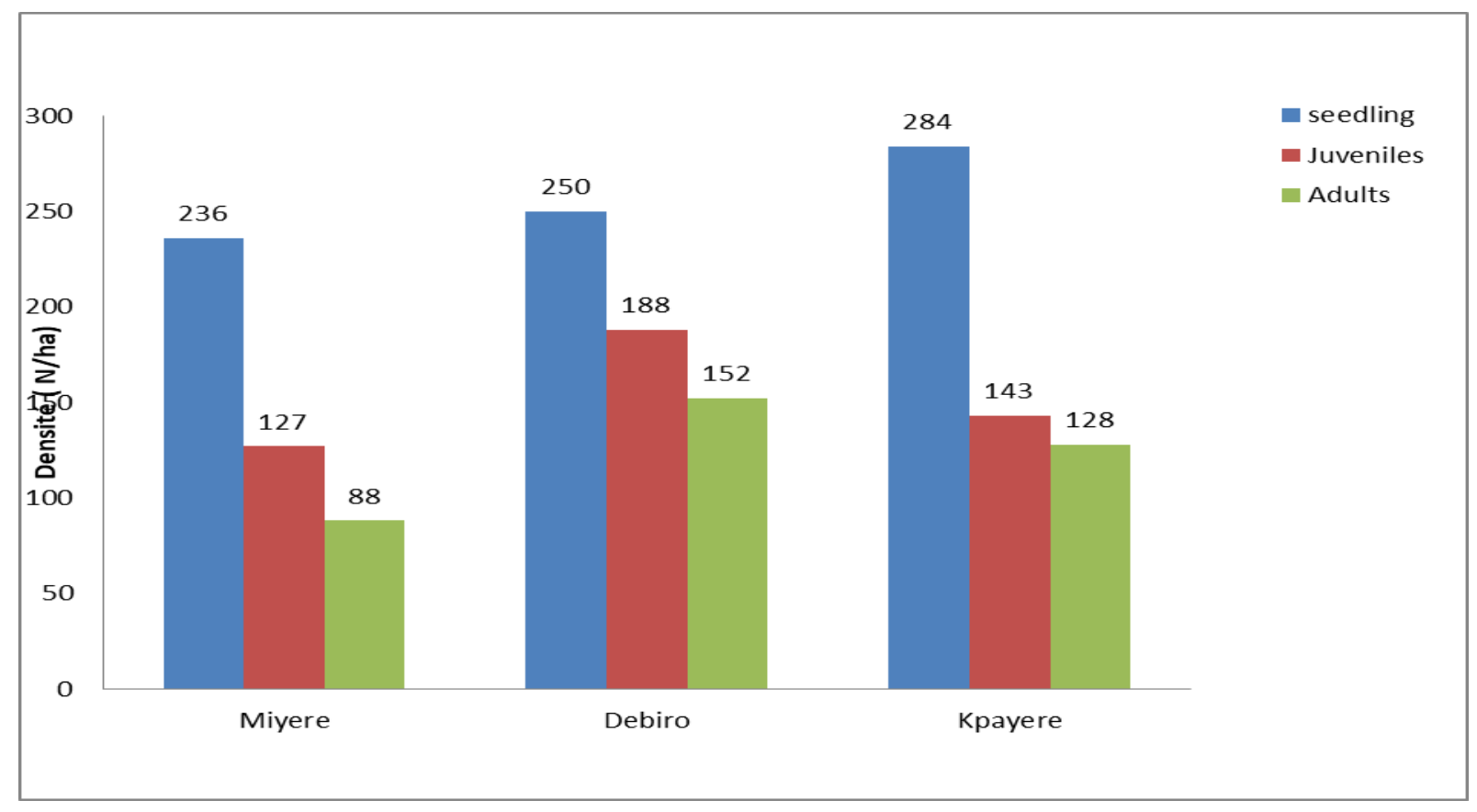

Fig. 3: Vertical structure of the woody stratum of PNMD.

This specific richness is relatively higher than that resulting from the study by Barima et al. (2016) and Ousmane et al. (2020) in Le Parc national du Mont Péko (PNMP) located in the western part of Côte d'Ivoire. In the savannahs of PNMD we observe a dominance of small individuals, reflecting a strong regeneration of the species. Semis represent $48.26 \%$, juveniles $28.69 \%$ and adults 23.05\%. This dominance of small individuals could be linked to the impact of bush fires permanently rejuvenating stands.

Samaya (2005) based on the maximum heights reached by antelopes (large, medium and small antelopes), indicates that it is beyond $3 \mathrm{~m}$ that woody trees become inaccessible to animals (exception made of elephant and giraffes). This categorization distinguishes seedlings, juveniles and adults. As a result, $76.95 \%$ of the woody individuals of the PNMD are accessible to wild herbivores.

The Shannon index is on average high in the PNMD but varies according to the sites. It is higher in Pkayere and lower in Debiro and Miyere. This reflects a particular dominance over the distribution of individuals of different species in Pkayere, but also a greater stability of this site compared to Debiro and Miyere. 
Woody vegetation is more balanced in Debiro and Kpayere, as evidenced by their relatively high fairness value compared to the other site. The different indices calculated in the PNMD combine to classify the three zones in terms of decreasing diversity, in the following order: Kpayere, Miyere, and Debiro

\section{Conclusions}

The present study made it possible to assess the floristic diversity of the savannas of the Mbam and Djerem National Park. This diversity is high compared to other agro-ecological zones in Cameroon. The woody diversity decreases from North to South while the indices increase. The study also corroborated the idea that the PNMD is a transition region between the agro-ecological sylvo-pastoral zone and that of the forest. Indeed, this northern part of the PNMD has a relatively low floristic diversity compared to the PNMD South, which confirms that this northern part is much more affected by human action, in particular that linked to pastoral activities.

\section{Conflict of interest statement}

The authors have not declared any conflict of interest.

\section{Acknowledgement}

This work was carried out with funding from PAAPNMD/ WCS, with the active collaboration of eco-guards and colleagues of the Department of Forestry of the FASA of Dschang University. The authors thank the leaders of these organizations.

\section{References}

Barima, Y. S. S., Kouakou, A. T. M., Bamba, I., Sangne, Y. C., Godron, M., Andrieu, J., Bogaert, J., 2016. Cocoa crops are destroying the forest reserves of the classified forest of Haut-Sassandra (Ivory Coast). Global Ecol. Conserv. 8, 85- 98.

Dayamba, S. D., 2005, Influence des feux de brousse sur la dynamique de la végétation dans le Parc W- Burkina, Mémoire de fin d'études d’Ingénieur du Développement Rural : option élevage, IDR/UPB-Burkina Faso, pp. 27-28.

Demers-Lemay, M., 2014. Le potentiel de la restauration écologique face à la colonisation des savanes par les espèces ligneuses Master a la Faculté des Sciences de Université de Sherbrooke, $89 \mathrm{p}$.

Gonzalez, P., 2001, Desertification and a shift of forest species in the West African Sahel, Climate Res. 17, 217-228.

Gregoire, J. M., Fournier, A., Eva, H., Sawadogo, I., 2003. Caractérisation de la dynamique des feux etde l'évolution du couvert dansle Parc du W: Burkina Faso, Bénin et Niger, Mission d'expertise pour l'étude des feux de brousse et leur utilisation dans le cadre d'une gestion raisonnée des aires protégées du Complexe WAP - UE, 2003, 64 p.

Miabangana, E.S., 2019. Analyse floristique, phytogéographique et phytosociologique de la végétation insulaire et riveraine du fleuve Congo dans le Plateau des Cataractes (République du Congo). Thèse de doctorat, Université de Kinshasa, Kinshasa : 303 p. + 91 annexes.

Michael, H., Kellee, K., Gill, B., Jennifer, C., Williams, K. J., 2016. Biodiversity Hotspots (Version 2016.1) [Data set]. Zenodo. Http://doi.org/10.5281/zenodo.3261807.

Consulté 13 octobre 2019, à l'adresse https://zenodo.org/record/3261807\#.XXZPNy hKh9M.

MINFOF (Ministère des Forêts et de la Faune), 2017. Plan d'aménagement du Parc National du Mbam et Djerem e de sa zone périphérique, Yaoundé, Cameroun: MINFOF.

N'dri, A. B., 2011. Interaction termite-feu et dynamique de la végétation en savane (LAMTO, Côte d'Ivoire), Thèse de doctorat, Université Paris 6, cotutelle avec l'Université d'Abobo-Adjamé, p, 175. Climatologie, Liège.

Ousmane, S., Henri, K. K., Armand, Z. D., Djaha, K., Traore, K., 2018. Dynamics of human pressures on the Mont Péko National Park (West-Côte d'Ivoire). Eur. Sci. J. 14(11), 109124.

Ousmane, S., Henri, K. K., Edouard, K.K. (2020). Etat Actuel de la Diversité Floristique du Parc National du Mont Péko en Côte d'Ivoire. European Scientific Journal,. URL:http://dx.doi.org/10.19044/esj.2020.v16 n3p341.

Ousmane, S., N’Da Dibi, H., Kouassi, K. H., Kouassi, K. E., Ouattara, K., 2020. Crises politico-militaires et dynamique de la 
végétation du Parc national du Mont Péko en Côte d'Ivoire. Bois et Forêts des Tropiques, 34:x-z.

Poupon, H., 1976, Influence de la sécheresse de l'année 1072-1973 sur la végétation d'une savane sahélienne du Ferlo septentrional, Sénégal. In « Désertification au Sud du Sahara ", Coll. Nouakchott du 17-19 déc. 1973 : 1996101.

Sarr, M. A., 2009. Évolution récente du climat et de la végétation au Sénégal (cas du Ferlo), Thèse de doctorat, Université Jean Moulin Lyon 3, LCRE UMR 5600 CNRS, 410 p.
Sawadogo, L., 2012. L'influence des feux sur la biodiversité des savanes ouest africaines, Atlas de la Biodiversité de l'Afrique de l'Ouest, Côte d'Ivoire, Tome III, BIOTA, pp.72-73.

Wezel, A., 2004, Local knowledge of vegetation changes in Sahelian Africa - implications for local resource management. In The Sahel Current politics in West Africa- The use of local knowledge in applied research-Participation in project planning and capacity building, Serein occasional paper 17, Lykke A.M., Due M.K., Kristensen M. and, Nielsen I. (eds.), pp. 37-51.

\section{How to cite this article:}

Christelle, D. G., Martin, T. N., FOTSO, R. C., 2020. Floristic diversity of woody stands of the Sudano Guinean Savannah of Mbam and Djerem National Park (PNMD), Cameroon. Int. J. Curr. Res. Biosci. Plant Biol. 7(9), 1-9. doi: https://doi.org/10.20546/ijcrbp.2020.709.001 